\title{
TEKNOLOGI GLOBAL POSITIONING SISTEM (GPS) UNTUK PELAPORAN DAN PENJEMPUTAN SAMPAH BERBASIS ANDROID
}

\author{
Saeful Bahri ${ }^{1}$, Satia Suhada ${ }^{2}$, Jamal Maulana Hudin ${ }^{3}$ \\ ${ }^{123}$ STMIK Nusa Mandiri Jakarta
}

Jalan Damai No. 8 Warung Jati Barat Jakarta Selatan, 12540 Indonesia

${ }^{1}$ Saeful.sel@nusamandiri.ac.id, ${ }^{2}$ Satia.shq@nusamandiri.ac.id, ${ }^{3}$ Jamal.jml@nusamandiri.ac.id

\begin{abstract}
Abstrak - Teknolgi GPS merupakan salah satu teknologi navigasi yang memanfaatkan lebih dari 30 satelite yang mengorbit di $20.000 \mathrm{~km}$ diatas permukaan bumi, GPS telah banyak dimanfaatkan untuk berbagai keperluan seperti bidang militer bidang tranportasi dan beberapa bidang lainnya, pada penelitian ini teknologi GPS akan dimanfaatkan untuk menentukan sebuah lokasi tumpukan sampah. Sampah merupakan sebuah masalah di banyak negara didunia tidak terkecuali di Indonesia, sampah merupakan salah satu sumber penyakit jika dibiarkan begitu saja tanpa adanya penanganan, kebiasaan masyarakat dalam membuang sampah secara sembarangan, selain kesadaran dari masyarakat, salah satu yang mempengaruhi prilaku buang sampah sembarangan adalah keterbatasan akses terhadap petugas kebersihan, begitu juga masalah yang dialami oleh petugas kebersihan banyak titik sampah tidak diketahui dan dibiarkan begitu saja hal ini menyebabkan sampah semakin menumpuk, pemanfaatkan teknologi geo tagging pada Global Positiong system (GPS) dapat mempermudah masyarakat dalam pelaporan titik dimana sampah terkumpul yang tidak di ketahui oleh petugas sampah sebelumnya, sehingga petugas pengangkut sampah bisa dengan mudah menemukan titik penjemputan sampah, dengan adanya penandaan lokasi dan pengankutan sampah diharapakan adanya komunikasi aktif antara masyarakat dan petugas kebersihan sehingga tumpukan sampah di titik-titik yang tadinya sulit dijangkau menjadi bisa ditangani lebih cepat
\end{abstract}

Keywords - Geo tagging, GPS, Sampah

\section{PENDAhuluan}

Dokumen GPS merupakan salah satu teknologi teknologi navigasi [1][2] yang telah dimanfaatkan untuk berbagai keperluan seperti militer, pemetan wilayah [3] bahkan untuk transportasi [4], pada penelitian ini kami akan menerapkan system GPS untuk penandaan titik di suatu wilayah yang terdapat tumpukan sampah.

Hampir di seluruh negara di dunia, permasalahan sampah masih menjadi salah satu isu penting untuk dibahas [5], menurut BPS (2015) berdasarkan hasil kajian Intergovernmental Panel on Climate Change (IPCC) pada tahun 2007 memastikan bahwa sampah turut berkontribusi dalam meningkatkan perubahan iklim secara global. Dikatakan bahwa perubahan iklim global terjadi akibat atmosfer bumi dipenuhi oleh Gas Rumah Kaca (GRK), seperti karbon dioksida (CO2) dan gas metana $(\mathrm{CH} 4)$. Aktivitas pembuagan sampah inilah yang menghasilkan gas metana tersebut. Di Indonesia dengan jumlah penduduk sebanyak 255 juta jiwa pada tahun 2015 dengan tingkat kepadatan yang mencapai 135 ribu jiwa per km2 [6], sampah menjadi salah satu permasalahan utama, terutama di kota besar seperti jakarta menurut [7] sampah di kota jakarta pada tahun 2012 mencapai 7.896 ton sampah perhari, hal ini tentu akan menjadi masalah besar terhadap linkungan, jika tidak ada kesadaran dan kepedulian dari masyarakat dan pemerintah dalam hal ini dinas persampahan.

Selain perilaku membuang sampah secara sembarangan dengan jumlah penduduk yang banyak, faktor pertambahan jumlah penduduk turut mengakibatkan peningkatan produksi sampah di
Indonesia [8], Kebiasaan masyarakat dalam membuang sampah secara sembarangan ini dipengaruhi oleh beberapa faktor salah satunya yaitu terbatasnya akses masyarakat kepada petugas kebersihan di kota atau daerah tersebut, hal ini menyebabkan masyakat lebih memilih untuk membuang sampah secara sembarangan, para petugas kebersihan pun disulitkan dengan menemukan titik dimana sampah itu terkumpul dan seringkali sampah yang terkumpul tersebut terlewat untuk diangkut ke tempat pembuangan sampah akhir.

Oleh karena itu, solusi untuk mempermudah akses antara masyarakat dengan petugas kebersihan, kami mencoba mengajukan sebuah sistem untuk menentukan titik dimana sampah terkumpul, kemudian titik kumpul sampah tersebut akan dijemput oleh petugas kebersihan. Kami memanfaatkan teknologi geotagging untuk menentukan titik dimana sampah tersebut berada dan geolocation untuk mencari dimanasajakah titik-titik sampah tersebut berada, yang akan dijemput oleh petugas kebersihan. Sistem ini akan kami aplikasikan kedalam sebuah sistem perangkat lunak. Sistem ini diharapkan akan mampu membantu masyarakat dalam menghubungi petugas kebersihan dan menujukan secara langsung titik dimana sampah tersebut terkumpul, begitu juga petugas akan dimudahkan dalam menemukan titik sampah tersebut.

\section{TINJAUAN PUSTAKA}

A. GPS (Global Positioning Sistem)

Positioning Sistem (GPS) merupakan sebuat teknologi navigasi yang memanfaatkan lebih dari 30 satelit yang mengorbit pada ketinggian $20.000 \mathrm{~km}$ 
diatas permukaan bumi. Pada awalnya teknologi ini hanya digunakan untuk dunia militer, namun untuk saat ini teknologi GPS teah banyak ditemukan pada perangkat-perangkat, seperti perangkat telepon seluler dan beberapa perangkat navigasi yang dapat memerima sinyal radio dari satellite. Ketika kita

Page $\mid 40$ berada disuatu tempat setidaknya ada empat satellite yang dapat dijangkau, masing-masing dari satellite tersebut memberikan informasi lokasi secara realtime, kecepatan sinyal dalam yang di transmisikan menyamai kecepatan cahaya sehingga pesan yang diterima cukup cepat [1]

Dalam menentukan lokasi GPS setidaknya membutuhkan 3 buah satellite yang disebut triateration

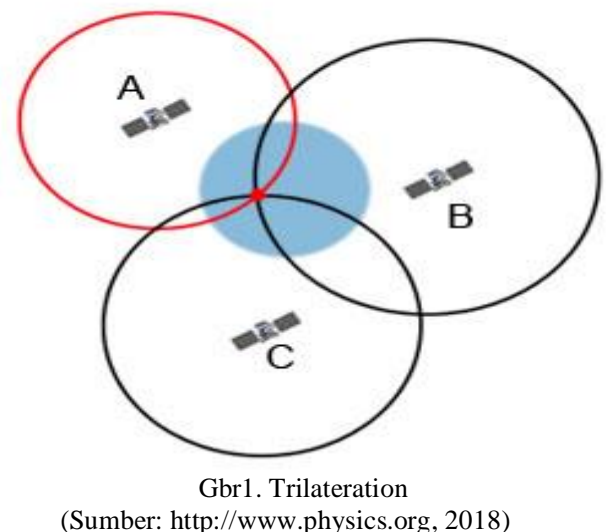

Pada penelitian ini teknologi GPS akan digunakan untuk memberikan navigasi, terhadap petugas pengambil sampah dan menentukan titk pengambilan sampah, dengan menggunakan teknik geo tagging.

\section{$B$.}

\section{Penelitain Terakhir}

Beberapa penelitian terkait tentang pengelolaaan sampah menggunakan teknologi baik itu sistem informasi dan teknologi GPS itu sendiri telah banyak dilakukan oleh beberapa peneliti diantaranya:

Pada penelitian yang dilakukan oleh [9] Suryanto dan widjadja kusuma yang berjudul Kajian Sistem Pengangkutan Sampah Kota Depok, penelitian tersebut membahas tentang kebijakan sistem pengangkutan sampah, dari penelitian tersebut didapat beberapa kebijakan dalam proses pengangkutan sampah seperti menggeser waktu pemberangkatan dari TPA, perubahan sistem pengumpulan sampah dari door to door menjadi sistem container dan penambahan personel pengangkut sampah,

Penelitian berikutnya dari [10] yang berjudul Pembuangan Sampah Terdekat Di Kota Jambi Berbasis Android ( Studi Kasus : Dinas Kebersihan Kota Jambi ), penelitian tersebut membahas tentang pembuatan sistem informasi pencarian tempat sampah terdekat dengan aplikasi android, pada penelitian tersebut pengguna mencari tempat pembuangan sampah yang terdekat menggunakan teknologi GPS.

Penelitian berikutnya yang dilakukan oleh [11] yang berjudul Sistem Informasi Pengolahan Sampah
Di Pondok Pesantren Nurul Jadid, penelitian tersebut membahas tentang pembuatan sistem informasi pengelolaan sampah yang dikhusukan untuk lingkungan pondok pesantren panelitian tersebut membangun sebuah sistem informasi bank sampah yang diimplemntasikan kedalam aplikasi desktop.

Penelitian yang telah dilakukan oleh [12] yang berjudul Aplikasi Sistem Informasi Geografis Untuk Arahan Rute Optimal Truk Pengangkut Sampah Menuju Tpa Piyungan Dari Tps Di Kabupaten Sleman Bagian Selatan membahas tentang pemanfaatan SIG yang didalamnya terdapat teknologi GPS untuk penunjukan rute truk pengangkut sampah.

Penelitian yang telah dilakukan oleh [13] dengan judul Sistem Informasi Geografis Pelaporan Masyarakat (Sigma) Berbasis Foto Geotag, yang membahas tentang pemanfaatan teknologi geotag dalam penandaan titik lokasi pelaporan masalahmasalah sosial yang ada dimasyarakat.

Perbedaan penelitian terhadap penelitian yang dilakukan oleh beberapa peneliti tersebut dapat dilihat dalam table 1

TABEL I

PERBEDAAN PENELITI TERDAHULU

\begin{tabular}{|c|c|c|c|}
\hline $\begin{array}{c}\text { Judul } \\
\text { Penelitian }\end{array}$ & Penulis & Pembahasan & Pebedaan \\
\hline $\begin{array}{l}\text { Kajian } \\
\text { Sistem } \\
\text { Pengangkuta } \\
\text { n Sampah } \\
\text { Kota Depok }\end{array}$ & $\begin{array}{l}\text { Suryantol, } \\
\text { Doddy Ari } \\
\text { Widjadjak } \\
\text { usuma, } \\
\text { Jack }\end{array}$ & $\begin{array}{l}\text { Tentang } \\
\text { pembuatan } \\
\text { kebijakan } \\
\text { mengena } \\
\text { sistem } \\
\text { pengangkutan } \\
\text { sampah secara } \\
\text { konvensional }\end{array}$ & $\begin{array}{l}\text { Pembuatan } \\
\text { sistem } \\
\text { pelaporan } \\
\text { via aplikasi } \\
\text { mobile } \\
\text { android }\end{array}$ \\
\hline $\begin{array}{l}\text { Pembuangan } \\
\text { Sampah } \\
\text { Terdekat Di } \\
\text { Kota Jambi } \\
\text { Berbasis } \\
\text { Android }\end{array}$ & $\begin{array}{l}\text { Choiri, } \\
\text { Eifel Rio } \\
\text { Beny } \\
\text { Nugroho, } \\
\text { Agus }\end{array}$ & $\begin{array}{l}\text { Membangun } \\
\text { sistem } \\
\text { pencarian } \\
\text { tempat } \\
\text { sampah } \\
\text { tedekat } \\
\text { menggukanan } \\
\text { teknologi GPS } \\
\text { dan geo } \\
\text { tagging }\end{array}$ & $\begin{array}{l}\text { Melakukan } \\
\text { pencarian } \\
\text { pengangkut } \\
\text { sampah } \\
\text { terdekat } \\
\text { agar } \\
\text { tumpukan } \\
\text { sampah } \\
\text { segera bisa } \\
\text { ditangani } \\
\end{array}$ \\
\hline $\begin{array}{l}\text { Sistem } \\
\text { Informasi } \\
\text { Pengolahan } \\
\text { Sampah Di } \\
\text { Pondok } \\
\text { Pesantren } \\
\text { Nurul Jadid }\end{array}$ & $\begin{array}{l}\text { Faid, } \\
\text { Mocham } \\
\text { mad } \\
\text { Jasri, Moh }\end{array}$ & $\begin{array}{l}\text { Pembuatan } \\
\text { aplikasi bank } \\
\text { sampah yang } \\
\text { bertujuan } \\
\text { memantau } \\
\text { pengendalian } \\
\text { sampah di } \\
\text { linkgungan } \\
\text { pondok }\end{array}$ & $\begin{array}{l}\text { Pembuatan } \\
\text { aplikasi } \\
\text { pelapona } \\
\text { dang } \\
\text { pengangkut } \\
\text { samapah } \\
\text { untuk } \\
\text { penangana } \\
\text { n sampah } \\
\text { segera }\end{array}$ \\
\hline $\begin{array}{l}\text { Aplikasi } \\
\text { Sistem } \\
\text { Informasi } \\
\text { Geografis } \\
\text { Untuk } \\
\text { Arahan Rute } \\
\text { Optimal } \\
\text { Truk } \\
\text { Pengangkut }\end{array}$ & Wijanarko & $\begin{array}{l}\text { Pemanfaatan } \\
\text { teknologi GPS } \\
\text { untuk } \\
\text { penunjukan } \\
\text { rute terpendek }\end{array}$ & $\begin{array}{l}\text { Peamanfaat } \\
\text { an } \\
\text { teknologi } \\
\text { GPS untuk } \\
\text { menunjuka } \\
\text { n lokasi } \\
\text { dan tempat } \\
\text { penjemputa } \\
\text { n sampah }\end{array}$ \\
\hline
\end{tabular}




\begin{tabular}{|c|c|c|c|c|}
\hline \multirow{2}{*}{ Page 41} & $\begin{array}{l}\text { Sampah } \\
\text { Menuju Tpa } \\
\text { Piyungan } \\
\text { Dari Tps Di } \\
\text { Kabupaten } \\
\text { Sleman } \\
\text { Bagian } \\
\text { Selatan }\end{array}$ & & & \\
\hline & $\begin{array}{l}\text { Sistem } \\
\text { Informasi } \\
\text { Geografis } \\
\text { Pelaporan } \\
\text { Masyarakat } \\
\text { (Sigma) } \\
\text { Berbasis } \\
\text { Foto Geotag }\end{array}$ & Mardani & $\begin{array}{l}\text { Pemanfaatna } \\
\text { teknologi foto } \\
\text { geotag untuk } \\
\text { pelaporan } \\
\text { masalah sosial } \\
\text { dimasyaratak }\end{array}$ & $\begin{array}{l}\text { Pemanfaata } \\
\mathrm{n} \text { teknologi } \\
\text { geotag } \\
\text { untuk } \\
\text { pelapoan } \\
\text { titik } \\
\text { sampah }\end{array}$ \\
\hline
\end{tabular}

\section{METODE PENELITIAN}

Penelitian ini merupakan hasil dari observasi tentang kebutuhan pelayanan masyarakat tentang persampahan, hasil dari penelitian ini berupa prototype perangkat lunak system informasi pelaporan dan pengangkutan sampah. Metode yang digunakan dapat dilihat pada gambar 2 .

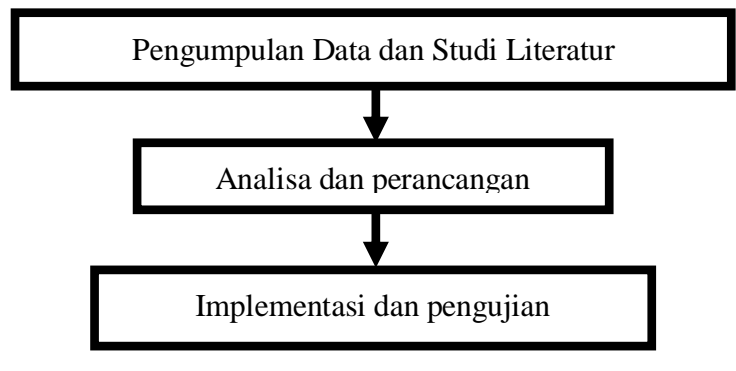

Gbr 2. Diagram Metode Penelitian

(Sumber: http:olahan penelitian, 2018)

Dari gambar 1 metode penelitian dapat dijelaskan sebagai berikut:

1. Pengumpulan data dan studi literature pada bagian ini, pengumpulan data dilakukan dengan cara wawancara dengan pihak dinas persampahaan, selain dinas persampahan beberapa masyarakat yang mejadi objek wawancara, selain melakukan wawancara studi literature juga dilakukan untuk mencari model dari perangkat lunak yang terbaik, yaitu dengan cara mencari dan menganalisa tentang kebutuhan dari model perangkat lunak yang akan dirancang ke prototype.

2. Analisa dan perancangan, setelah diketahui beberapa permasalah, cara penyelesaian masalah dan jenis perangkat lunak terbaik yang akan digunakan, kemudian dianalisa kembali untuk melihat proses yang saat ini sedang berjalan pada proses pengangkutan dan penangan sampah yang ada. Selanjutnya dirumuskan syarat funsionalitas dari system untuk kemudian di lakukan perancangan dari user interface prototype aplikasi yang dibangun.

Implementasi dan pengujian, pada tahapan ini hasil dari analisa dan perancangan diterapkan pada Bahasa pemrograman java berbasis mobile android, selanjutnya model prototype aplikasi dilakukan pengujian dengan meggunakan pegujian black box.

\section{HASIL DAN PEMBAHASAN}

Hasil analisis berupa syarat dan fungsional system yang dirancang kedalam diagram use case yang terdapat pada



Gbr 3. Use case diagram Aplikasi

Dari gambar 3. Ditunjukan bahwa actor pengguna berinteraksi dengan aplikasi dibagi kedalam 2 aktivitas interaksi diantaranya pengguna menetukan titik sampah dengan cara menandai dengan location pada GPS yang terdapat pada perangkat selularnya, setelah titik sampah ditendai kemudian pengguna mencari petugas yang akan mengangkut tumpukan sampah yang ada. Petugas menuju titik dimana sampah terumpul kemudia petugas melakukan pengangkutan sampahh tersebut.

Pada penelitian ini rancanggan system diimplemnetasikan kedalam aplikasi mobile android, dimulai dari merancan UX design, implementasi coding hingga pengujian sistem secara blakbox. Aplikasi ini dapat berjalan pada minimum android versi 4.0 atau Jely Bean.

\section{A. Implementasi}

Tampilan antar muka PELPAH-APP ini dapat dilihat pada gambar dibawah ini. Halaman utama menujukan beberapa menu yang dapat digunakan oleh pepengguna diantaranya lapor sampah digunakan untuk mencari dan menemukan petugas samapah tampilan halaman tersebu dapat dilihat pada gambar 5, menu riwayat lapor digunakan untuk melihat riwayat atau histori tampilan halama dapat dilihat ada gambar 5 , kemudian menu $5 \mathrm{M}$ tip digunakan untuk menampilkan tips tentang pencegahan demam berdarah sedangakan menu tentang aplikasi digunakan untuk melihat sekilas kegunaan dan fungsi dari aplikasi dapat dilihat pada gambar 7 . 


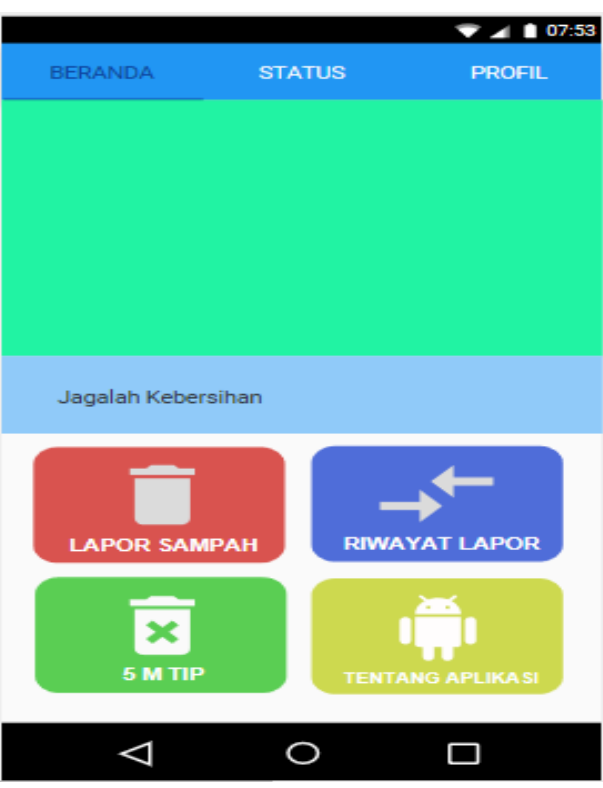

Gbr 4. Halaman Awal Aplikas

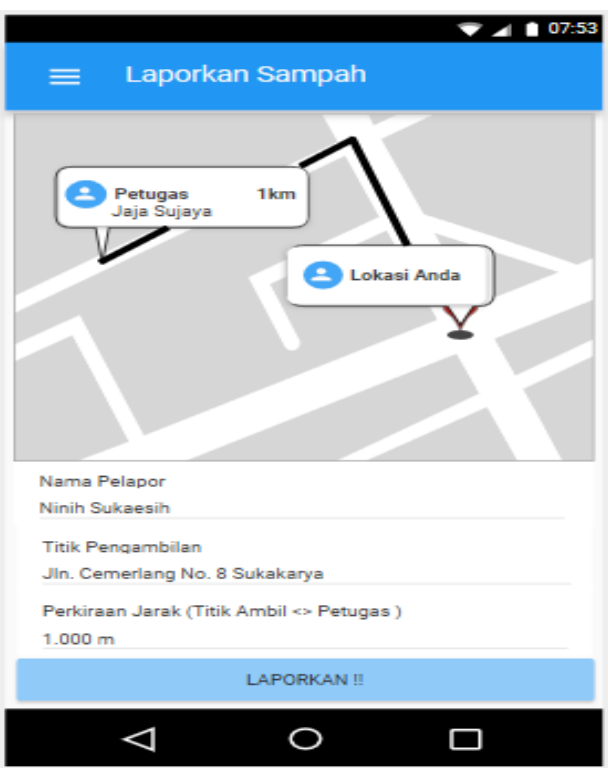

Gbr 5. Halaman Pencarian Petugas

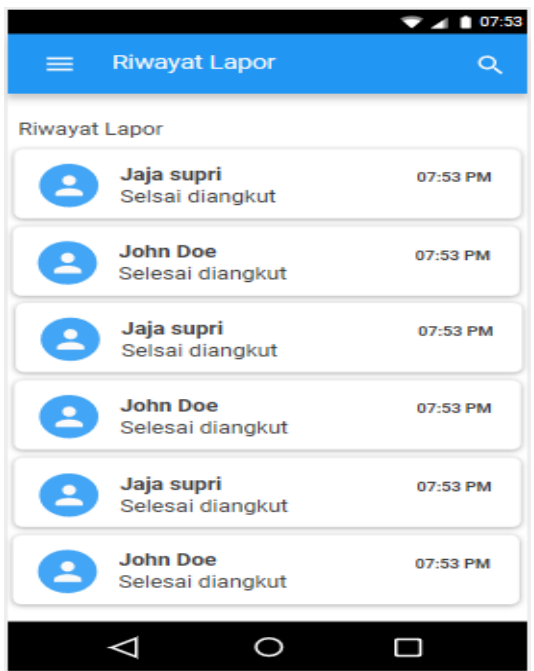

Gbr 6. Halaman Riwayat Lapor

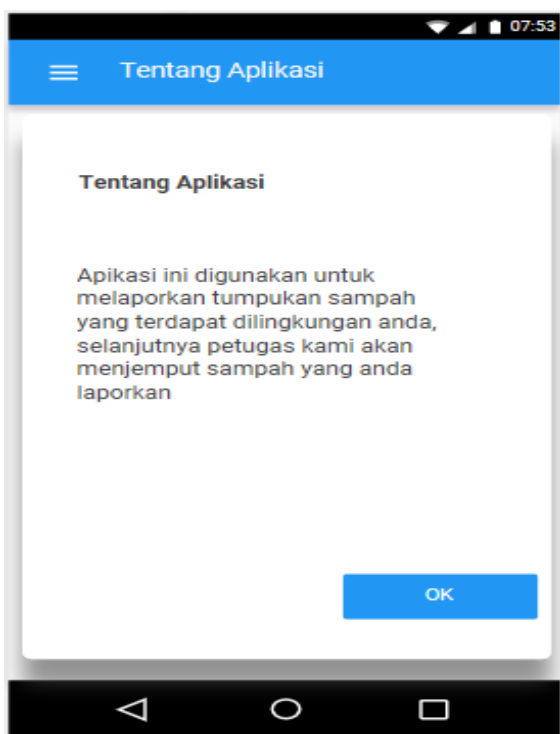

Gbr 7. Halaman Tentang Aplikasi

\section{B. Pengujian}

Pengujian terhadap aplikasi dilakukan dengan menggunakan teknik black box, yaitu menguji secara satu persatu halaman tombol dan fitur secara fungsional, setelah dilakukan pengujian fungsional secara keseluruhan maka aplikasi sudah memenuhi syarat dan kriteria fungsional.

TABEL II

TABEL PENGUJIAN BLACK BOX

\begin{tabular}{|c|c|c|c|}
\hline $\begin{array}{l}\mathrm{N} \\
\mathrm{o} .\end{array}$ & $\begin{array}{l}\text { Skema } \\
\text { pengujian }\end{array}$ & Hasil yang diharapkan & $\begin{array}{l}\text { Kesim } \\
\text { pulan }\end{array}$ \\
\hline 1. & $\begin{array}{l}\text { Membuka } \\
\text { aplikasi tanpa } \\
\text { pengaktifkan } \\
\text { Fitur GPS }\end{array}$ & $\begin{array}{l}\text { Fitur GPS secara } \\
\text { otomatis aktif dan } \\
\text { mencari lokasi default }\end{array}$ & Valid \\
\hline 2. & $\begin{array}{l}\text { Menonaktifka } \\
\text { n Fitur GPS }\end{array}$ & $\begin{array}{l}\text { Aplikasi } \\
\text { menamampilkan pesan } \\
\text { GPS tidak Aktif }\end{array}$ & Valid \\
\hline 3. & $\begin{array}{l}\text { Memilih } \\
\text { menu Lapor } \\
\text { sampah pada } \\
\text { menu utama }\end{array}$ & $\begin{array}{l}\text { Apikasi menampilkan } \\
\text { halaman yang memuat } \\
\text { MAPS beserta petugas } \\
\text { terdekat yang akan } \\
\text { mengangkut sampah }\end{array}$ & Valid \\
\hline 4. & $\begin{array}{l}\text { Menekan } \\
\text { tombol lapor }\end{array}$ & $\begin{array}{l}\text { Aplikasi khusus petugas } \\
\text { menampilkan notifikasi } \\
\text { bahwa ada titik sampah } \\
\text { terdekat }\end{array}$ & Valid \\
\hline 5. & $\begin{array}{l}\text { Menekan } \\
\text { tombol menu } \\
\text { riwayat lapor }\end{array}$ & $\begin{array}{l}\text { Aplikasi menampilkan } \\
\text { halaman riwayat lapor } \\
\text { berupa Llist yang } \\
\text { memuat history data } \\
\text { petugas pengangkut } \\
\text { status pengangkutan } \\
\text { beserta waktu } \\
\text { pengankutan }\end{array}$ & Valid \\
\hline 6. & $\begin{array}{l}\text { Menekan } \\
\text { tombol menu } \\
\text { tenang } \\
\text { aplikasi }\end{array}$ & $\begin{array}{l}\text { Apikasi menampilkan } \\
\text { haalamn yang memuat } \\
\text { tentang manfaat dan } \\
\text { kegunaan apalikasi }\end{array}$ & Valid \\
\hline
\end{tabular}

(Sumber: hasil pengujian penelitian, 2018) 


\section{KESIMPULAN DAN SARAN}

Prototype aplikasi pelopran dan pengangkutan sampah telah berhasil dikembangkan dan diujikan sehingga sesuai dengan fungionalitas yang telah di tetapkan. Metode yang diterpakan dalam pengembangan prototype ini meliputi metode

Page | 43 wawancara studi literature dan observasi, selanjutnya data hasil studi literature dan observasi tersebut dirancang kedalam bentuk UX Design kemudian UX Design tersebut diimplementasikan kedalam Bahasa pemrograman java, setelah proses implementasi selesai selanjutnya aplikasi dilakukan pengujian secara fungsional menggunakan metode black box.

Untuk mendapatkan hasil dari aplikasi yang cukup baik perlu adanya pengembangan dari sisi algoritma pencarian rute, kami menyarankan untuk penelitian selanjutnya dapat menggunakan algortima sortes path , Genetik algoritma aatu algoritma sejenisnya.

\section{REFERENSI}

[1] IOP Institut Of Physics, "How does GPS work?," physics.org, 2018. [Online]. Available: http://www.physics.org/articlequestions.asp?id=55.

[2] D. A. C. G.G. Liversidge, K.C. Cundy, J.F. Bishop, "United States Patent (19) 54,” vol. 96, no. 19, pp. 62-66, 1980.

[3] P.-Z. Z. Z. S. M. W. W. G. R. B. P. M. Q. W. Z. N. J. S. J. W S. H. Y. Xinzhao, "Continuous deformation of the Tibetan Plateau from global positioning system data," Geo Sci., vol. 32, no. 9, 2004.

[4] S. Dabiri and K. Heaslip, "Inferring transportation modes from GPS trajectories using a convolutional neural network," Transp. Res. Part C Emerg. Technol., vol. 86, no. December 2017, pp. 360-371, 2018.

[5] Y. C. Dai et al., "Why doorstepping can increase household waste recycling," Resour. Conserv. Recycl., vol. 102, pp. 9$19,2015$.

[6] BPS, "Badan Pusat Statistik," Tabel Dinamis, 2015. [Online]. Available: https://www.bps.go.id/site/resultTab. [Accessed: 19-Jan-2018].

[7] D. Hoornweg and P. Bhada, "What a Waste. A Global Review of Solid Waste Management," Urban Dev. Ser. Knowl. Pap., vol. 281, no. 19, p. 44 p., 2012.

[8] A. Mulyadi, S. Husein, and Z. Saam, "Perilaku masyarakat dan peranserta pemerintah daerah dalam pengelolaan sampah di kota tembilahan," Ilmu Lingkung., vol. 3, no. 2, pp. 147$162,2010$.

[9] D. A. Suryantol, J. Widjadjakusuma, F. Teknik, P. Universitas, J. Margonda, and R. No, "Kajian Sistem Pengangkutan Sampah KOta Depok," J. Fak. Tek. Sipil Perenc. Univ. Gunadarma, no. ISSN:18582559, pp. 23-24, 2005.

[10] E. R. Choiri, Beny, and A. Nugroho, "Pembuangan Sampah Terdekat Di Kota Jambi Berbasis Android ( Studi Kasus: Dinas Kebersihan Kota Jambi )," J. Ilm. Media Process., vol. Vol.10, no. No.2, pp. 556-569, 2015.

[11] M. Faid, M. Jasri, T. Informatika, S. Tinggi, and T. Nurul, "Sistem informasi pengolahan sampah di pondok pesantren nurul jadid," pp. 3-7, 2017.

[12] A. Wijanarko, "Aplikasi Sistem Informasi Geografis Untuk Arahan Rute Optimal Truk Pengangkut Sampah Menuju Tpa Piyungan Dari Tps Di Kabupaten Sleman Bagian Selatan," J. student Uiversitas Negeri Yogyakarta, vol. 2, no. 3, pp. 321333, 2017.

[13] A. Mardani, "Sistem Informasi Geografis Pelaporan Masyarakat (SIGMA) Berbasis Foto Geotag," J. Sist. Dan Teknol. Inf., vol. 3, no. Vol 3, No 1 (2014), 2014. 